\title{
Effect of a Short Time Post Carbon Tetrachloride Treatment Interval on Rat Plasma Enzyme Levels and Percentage Mortality
}

\author{
OBI, F.O* ${ }^{+}$; OMOGBAI, L.A.; ORIAFO, O.S.J.; OVAT, O.D. \\ Department of Biochemistry, Faculty of Science, University of Benin, P.M.B. 1154, Benin City, Edo state, Nigeria
}

\begin{abstract}
The effect of a short time (3 hours) post carbon tetrachloride treatment interval on rat plasma enzyme levels and percentage mortality have been examined. Relative to their corresponding activities in the plasma of carbon tetrachloride-free rats the activities of plasma L-aspartate aminotransferase, L-alanine aminotransferase and alkaline phosphatase of carbon tetrachloride treated rats were statistically significantly $(\mathrm{P}<0.05)$ increased when the rats were sacrificed 3 hours post exposure. During this period no mortality occurred. These results indicate that plasma enzyme levels can still be used as indices of carbon tetrachloride-induced tissue damage within a short exposure time rather than a longer post-exposure interval, which carries the risk of an unacceptably high rate of mortality. @ JASEM
\end{abstract}

Naturally carbon tetrachloride $\left(\mathrm{CCl}_{4}\right)$ was believed to be found in the troposphere by solar-induced photochemical reactions of chlorinated alkanes (Singh et al., 1975) but this does not appear to be the major source of environmental $\mathrm{CCl}_{4}$. It has been detected in volcanic emission gases (Isidorov et al., 1990). Several studies have shown that global atmospheric levels of $\mathrm{CCl}_{4}$ can be attributed to anthropogenic sources alone (Singh, et al., 1976). $\mathrm{CCl}_{4}$ can be produced directly by chlorination of methane, methanol, carbon disulphide, propane, 1,2dichloroethane and higher hydrocarbons and indirectly as a by-product during the manufacture of other products and compounds and during wood pulp bleaching (US EPA, 1984a).

Carbon tetrachloride like a number of other chemicals can cause cell or tissue necrosis. Tissue damage or death leads to the leakage of the enzyme produced in the affected tissue(s) into the bloodstream (Jaeger et al., 1975; Magos et al., 1982; Siegers et al., 1985). Hence serum or plasma enzyme levels have be used as indices for monitoring chemically induced tissue damages (Ngaha et al., 1989; Lin and Wang, 1986). Following the administration of such chemicals to experimental animals a time interval of 12 - 48 hours is often allowed to elapse before the surviving animals are sacrificed and the plasma/serum enzyme activities analysed (De Zwart et al., 1997).

We adopted this long time interval in a number of studies on the effect of anthocyanin on $\mathrm{CCl}_{4}$ - induced liver damage (Obi and Ozoemena, 1998; Obi et al., 1998; Obi and Okokoro, unpublished results) and in our experience this was usually accompanied by high mortality rate. Therefore, the purpose of this investigation was to find out whether a short post $-\mathrm{CCl}_{4}$ treatment interval could lead to higher survival rate and reasonable increase in plasma/serum enzyme levels that could still allow the effect of this chemical agent to be satisfactorily monitored.

\section{MATERIALS AND METHODS}

Animals: Ten white albino rats (Wistar strain) used for this experiment were obtained from NIMR, Lagos, Nigeria. They were maintained after purchase for 7 days on rat chow and water ad libitum before the commencement of the experiment.

Chemicals: Absolute ethanol and carbon tetrachloride were the products of BDH Chemical Company Ltd (Poole, England) and Hopkins and Williams respectively. Other materials include corn oil (Mazola produced for CPC, UK) and rat chow (Pfizer, Nigeria, Plc).

Treatment of animals: The rats were divided into two experimental groups of 5 rats each. Rats in-group I (normal control) were given 50\% aqueous ethanol by gavage $(2.5 \mathrm{ml} / \mathrm{kg}$ body weight $)$ followed by subcutaneous injection of corn oil $(1.5 \mathrm{ml} / \mathrm{kg}$ body weight). Rats in group II were given $50 \%$ aqueous ethanol followed by $1.5 \mathrm{ml} / \mathrm{kg}$ weight of a $1: 1(\mathrm{v} / \mathrm{v}$ mixture of carbon tetrachloride and corn oil via the same routes described for group I rats.

Preparation of plasma: Three hours after the last treatment given to each group of rats, each rat was anaesthetised in chloroform saturated chamber. While under anaesthesia the thoracic region was opened to expose the heart. Blood was obtained by cardiac puncture by means of a $5 \mathrm{ml}$ hypodermic syringe and needle and placed in ice-cold heparinized bottles. The blood was centrifuged at $5000 \mathrm{rpm}$ (Spinette - Damon / IEC bench top centrifuge) for 5 min. The plasma samples were collected and left at $20^{\circ} \mathrm{C}$ until required.

\footnotetext{
*Corresponding Author

${ }^{+}$Present address: Department of Biochemistry, University of Port Harcourt, P.M.B. 5323, Port Harcourt River State Nigeria.
} 
Plasma protein and enzyme assay: Total plasma protein was quantified by using biuret reagent. Laspartate aminotransferase (L-AST) and L-alanine aminotransferase (L-ALT) activities in the plasma were determined at $37^{\circ} \mathrm{C}$ by colorimetric method of Reitman and Frankel (1957). The activities of alkaline phosphates were determined by the colorimetric method of Plummer (1978) using phenolphthalein monophosphate as substrate. The enzymes were assayed using reagents obtained from enzyme assay kits (QCA Laboratories, Spain).

Statistical analysis: The mean values of the control and test rats plasma activities of a given enzyme were compared using Student's t-test (Elzey, 1971). The significance level was set at $\mathrm{P}<0.05$.

\section{RESULTS AND DISCUSSION}

The percentage mortality and survival of rats in our earlier studies involving long post $\mathrm{CCl}_{4}$ interval and that of the present study of 3 hours post $\mathrm{CCl}_{4}$ are presented in Table 1. Plasma L-AST, L-ALT and alkaline phosphatase activities in the presence and absence of $\mathrm{CCl}_{4}$ are presented in Table 2. A significant increase $(\mathrm{P}<0.05)$ in the plasma activities of the three enzymes was observed in the $\mathrm{CCl}_{4}-$ treated rats when compared with that of the $\mathrm{CCl}_{4}-$ free (control) rats.

Table 1:

Percentage mortality and survival of rats exposed to $\mathrm{CCl}_{4}$

$\begin{array}{lccccc}\text { Expt. \# } & \begin{array}{c}\text { Initial No. of } \\ \text { rat }\end{array} & \begin{array}{c}\text { Final No of } \\ \text { rats }\end{array} & \begin{array}{c}\text { Post } \mathrm{CCl}_{4} \\ \text { interval (h) }\end{array} & \text { \% Mortality } & \text { \% Survival } \\ \mathrm{I}^{\mathrm{a} *} & 10 & 5 & 18 & 50.0 & 50.0 \\ \mathrm{II}^{\mathrm{a} *} & 20 & 14 & 18 & 30.0 & 70.0 \\ \mathrm{III}^{\mathrm{a} * *} & 16 & 10 & 24 & 37.5 & 62.5 \\ \mathrm{IV}^{\mathrm{b} * *} & 5 & 5 & 3 & 0.0 & 100.0\end{array}$

${ }^{\mathrm{a}}$ I, II \& III are previous experiments. \{Obi and Ozoemena, 1998 (I); Obi et. al, 1998 (II); Obi and Okokoro-unpublised results (III) $\}$

${ }^{\mathrm{b}} \mathrm{IV}$, present study

* $\mathrm{CCl}_{4}$ administered by intraperitoneal injection (i.p)

** $\mathrm{CCl}_{4}$ administered by subcutaneous injection (s.i)

Table 2: $\quad$ Effect of $\mathrm{CCl}_{4}$ on plasma enzyme levels 3 hours post $-\mathrm{CCl}_{4}$

\begin{tabular}{|c|c|c|c|c|}
\hline \multirow[t]{2}{*}{ Group \# } & \multirow[t]{2}{*}{ Treatment } & \multicolumn{3}{|c|}{$\begin{array}{l}\text { Plasma Enzyme Activities } \\
\text { U/L/mean mg protein } \\
\text { Mean } \pm \text { SD }(n)^{\mathrm{a}}\end{array}$} \\
\hline & & $\mathrm{L}-\mathrm{AST}$ & $\mathrm{L}-\mathrm{ALT}$ & AP \\
\hline I(Control) & $-\mathrm{CCl}_{4}$ & $2.13+0.10(5)$ & $7.22+0.22(5)$ & $1.02+0.47(5)$ \\
\hline II(Test) & $+\mathrm{CCl}_{4}$ & $2.51 \pm 0.14(4)^{b, c}$ & $9.50 \pm 0.34(4)^{b}$ & $1.62+0.58(4)^{\mathrm{b}}$ \\
\hline
\end{tabular}

${ }^{\mathrm{a} A P}$ - Alkaline phosphatase; $\mathrm{n}$ - number of samples analysed.

${ }^{b}$ Values statistically significantly higher than the corresponding control

value $(\mathrm{P}<0.05)$.

'One of the samples in this group was lost post-sacrifice. Hence $n=4$.

When $\mathrm{CCl}_{4}$ is administered to rats orally, intraperitoneally or subcutaneously it is normal practice to allow 12 - 48 hours to elapse before tissue and blood analyses (De Zwart et al., 1997; Reinke et al., 1988). Within this period maximum levels of serum/plasma L-alanine aminotransferase and Laspartate aminotransferase (Teschke et al., 1983; Nakata et al., 1985) and glutamate dehydrogenase (Teschke et al., 1983) activities have been demonstrated. In our earlier studies in which a good number of rats died before the expiration of 24 hours the doses of $\mathrm{CCl}_{4}$ used were in the range of 0.5 $1.5 \mathrm{ml} \mathrm{CCl}_{4} / \mathrm{kg}$ body weight. This dose range is not outrageous. Other investigators have used $1.5 \mathrm{ml}$ (Teschke et al., 1983) $2.5 \mathrm{ml}$ (Dingell and Heimberg 1968; Moore et al., 1976) $1.25 \mathrm{ml}$ (Larson and Plaa 1965) and $2.0 \mathrm{ml}$ (Marchand et al., (1970) $\mathrm{CCl}_{4} / \mathrm{kg}$ body weight orally. Dose of $3 \mathrm{ml} / \mathrm{kg}$ body weight has been used (Hase et al., 1996) subcutaneously which is considerably higher than our dose. Most of these reports are silent on the issue of mortality of the experimental rat, which in a number of cases, are the 
same stain of rat we used. However since our doses are well within the dose range used by others we are inclined to attribute the death to the long post $\mathrm{CCl}_{4}$ interval instead of overdose.

Following intraperitoneal or subcutaneous injection of $\mathrm{CCl}_{4}$ the rats that did not survive started dying barely 4 hours post exposure. Based on this fact we decided to allow only 3 hours post exposure interval. This time period as reported by others is sufficient for an oral dose to reach peak levels in blood, liver, kidney, brain and muscle (Watanabe et al., 1986; Teschke et al., 1983). As the data presented in Table 1 reveals this time interval ensured that the rats remained alive until they were sacrificed. The three enzymes whose activities were analysed are frequently used for assessing liver injury (Ngaha et al., 1989; Lin and Wang, 1986; Teschke et al., 1983; Nakata et al., 1985; Magos et al., 1982; Jaeger et al., 1975; Siegers et al., 1985). Theoretically when an agent damages an organ the enzymes it elaborates leak into the bloodstream leading to increased serum or plasma activities of the biomarker enzymes. In order to demonstrate this change unequivocally sufficient post-exposure time, 12 - 48 hours, is allowed (De Zwart et al., 1997; Reinke et al., 1988). In this study a clear and significant margin was demonstrated between the activities of the enzyme in the plasma of $\mathrm{CCl}_{4}$ - free rats and $\mathrm{CCl}_{4}$ - treated ones. The increased enzyme activities in the plasma of $\mathrm{CCl}_{4}$ - treated rats suggests that the toxicant was able to reach the liver and induce detectable damage within 3 hours. It may, therefore, be worthwhile to consider and adopt a short post - $\mathrm{CCl}_{4}$ exposure time which not only allows a high survival rate but a reasonable increase in serum/plasma enzyme levels for assessing the toxic potency of this chemical.

A number of substances increase the biotransformation of $\mathrm{CCl}_{4}$ and potentiates its intoxication. Among the substances are high fat diet and ethanol (Strubelt, 1984; McCay et al., 1984; Reinke et al., 1988). Ethanol in particular is thought to be responsible for the induction of the cytochrome $\mathrm{P}_{450}$ isoenzyme involved in $\mathrm{CCl}_{4}$ bioconversion to metabolites that initiate lipid peroxidation and attendant tissue damage. Therefore in this study we treated both group of rats with $50 \%$ aqueous ethanol simply to achieve reasonable damage within 3 hours of $\mathrm{CCl}_{4}$ exposure.

\section{REFERENCE}

De Zwart. LL; Venhorst J; Groot, M; Commandeur, JN; Hermanns, RC; Meerman, JH; Fan Baar, BL; Vermaulen, NP (1997). Simultaneous determination of eight lipid peroxidation degradation products in urine of rats treated with carbon tetrachloride using gas chromatography with electron capture detection. J. Chromatog. Biomed. Appl. B694: 277 - 287.

Elzey, FF (1971). A programmed introduction to statistics, $2^{\text {nd }}$ edition. Brooks Cole Publishing Company, California, pp. 254 - 299.

Hase, K; Kadota, S; Basnet, P; Namba, T. and Takahashi, T. (1996) Hepatoprotective effect of traditional medicines. Isolation of the active constituent from seeds of Celosia argentea. Phytother. Res. 10, 387 - 392.

Isidorov, VA; Zenkerich, IG; Loffe, BV (1990). Volatile organic compounds in solfataric gases. J. Atmos. Che 10:329 - 340.

Jaeger, RJ; Conolly, RB; Murphy, SD (1975). Shortterm inhalation toxicity of halogenated hydrocarbon. Arch. Environ Health 30: 26 - 31.

Larson, RE; Plaa, GL (1965). A correlation of the effects of cervical cordotomy, hypothermia and catecholamines on carbon tetrachloride induced hepatic necrosis. J. Pharmacol. Exp. Ther. 147: $103-111$.

Lin, JK; Wang C.J (1986). Protection of crocin dyes in the acute hepatic damage induced by aflatoxin $\mathrm{B}_{1}$, and dimethylnitrosamine in rats. Carcinogenesis 7: 595 - 599.

Magos, L; Showden, R; White, INH; Butler, WH; Tuffery, AA (1982) Isotoxic oral and inhalation exposure of carbon tetrachloride in Porton Wistar and Fisher rats. J. Appl. Toxicol. 2: 238 240.

Marchand, C; McLean, S; Plaa, GL (1970). The effect of SKF 525A on the distribution of carbon tetrachloride in rats. J. Pharmacol. Exp. Ther. 174: $232-238$.

McCay, PB; Lai, EK; Poyer, JL; DuBose, CM; Janzen, EG (1984). Oxygen - and carbon centred free radical formation during carbon tetrachloride metabolism. Observations of lipid radicals in vivo and in vitro. J. Biol. Chem. 259: $2135-2143$.

Nakata, R; Tsukamoto, I; Miyoshi, M; Kojo, S. (1985). Liver regeneration after carbon tetrachloride intoxication in the rat. Biochem. Pharmacol. 34: 586 - 588.

Ngaha, EO; Akanji, MA; Madusolumuo, MA (1989). Studies on correlation between chloroquine - 
induced tissue damage and serum enzyme changes in the rat. Experientia 45: 143 - 146.

Obi, FO; Usenu, IA; Osayande, JO. (1998). Prevention of carbon tetrachloride - induced hepatotoxicity in the rat by $H$. rosasinensis anthocyanin extract administered in ethanol. Toxicology 131: 93 - 98.

Obi, FO; Ozoemena, D. (1998). Prevention of carbon tetrachloride - induced acute liver damage in the rat by $H$. rosasinensis anthocyanin extract administered in water. Biosci. Res. Commun. 10 (4): $241-246$.

Obi, FO; Okokoro, AA: An examination of the possible effects of $H$. rosasinensis petal anthocyanidin extract on carbon tetrachloride induced liver lipid peroxidation and plasma antioxidant enzyme levels in the rat (unpublished).

Plummer, DT (1978). An introduction to Practical Biochemistry, $3^{\text {rd }}$ edition. McGraw - Hill Book Company, Maidenhead, Berkshire. p. 347.

Reinke, LA: Lai. EK; McCay, PB (1988). Ethanol feeding stimulates trichloromethyl radical formation from carbon tetrachloride in liver. Xenobiotica 18: 1311 - 1318.

Reitman, S; Frankel, S (1957). Glutamic - pyruvate transaminase assay by colorimetric method. Am. J. Clin. Path 28: 56.
Siegers, CP; Horn, W; Younes, M. (1985). Effect of hypoxia on the metabolism and hepatotoxicity of carbon tetrachloride and vinylidene chloride in rats. Acta Pharmacol. Toxicol - 56: 81 - 86 .

Singh, HB; Lillian, D; Appleby, A; Lobhan, L (1975). Atmospheric formation of carbon tetrachloride from tetrachloroethlene. Environ. Lett, 10: 253 256.

Singh HB; Fowler, DP; Peyton, TO (1976). Atmospheric carbon tetrachloride: another manmade pollutant. Science 192: 1231 - 1234.

Strubelt, D. (1984). Alcohol potentiation of liver injury. Fundam. Appl. Toxicol 4: 144-151.

Teschke, R; Vierke, W; Goldermann, L (1983). Carbon tetrachloride $\left(\mathrm{CCl}_{4}\right)$ levels and serum activities of liver enzymes following $\mathrm{CCl}_{4}$ intoxication. Toxicol. Lett. 17: $175-180$.

US EPA (1984a). Locating and estimating air emissions from sources of carbon tetrachloride in Washington D.C. US Environmental Protection Agency Report No. 450/4 - 84 - 0067b.

Watanabe, A; Shiota, T; Takei, N; Fujiwara, M; Nagashima, H. (1986). Blood to brain transfer of carbon tetrachloride and lipoperoxidation in rat brain. Res. Commun. Chem.. Pathol. Pharmacol. 51: $137-140$. 